\title{
PERFORMANCES OF NEW ISOLATES OF BIFIDOBACTERIUM ON FERMENTATION OF SOYMILK
}

\author{
Petra HaVAS ${ }^{1}$, SzILÁrd KuN ${ }^{1}$, IZABell PERGER-MÉSZÁros², \\ JUdiT M. REZESSY-SZABÓ ${ }^{1}$ and QUANG D. NGUYEN ${ }^{1 *}$ \\ ${ }^{1}$ Department of Brewing and Distilling, Institute of Bioengineering, \\ Faculty of Food Science, Corvinus University of Budapest, Budapest, Hungary \\ ${ }^{2}$ Present address: Ceva-Phylaxia Corporation, Szállás utca 5, H-1107 Budapest, Hungary
}

(Received: 12 August 2015; accepted: 10 October 2015)

\begin{abstract}
Growth and metabolic activity of several new, human origin isolates of Bifidobacterium strains were investigated. All tested bifidobacteria strains were grown well on the native soymilk medium without any additional nutrients. The fermentation processes cultured with initial cell concentrations in $10^{5}-10^{7} \mathrm{cfu} / \mathrm{ml}$ resulted in $10^{8} \mathrm{cfu} / \mathrm{ml}$ after $8-12 \mathrm{~h}$ of incubation in soymilk, and were kept viable up to the end of fermentation ( $48 \mathrm{~h}$ ). Volumetric productivities of B. bifidum B3.2, B. bifidum B7.1 and $B$. breve B9.14 were $1.6 \times 10^{10} \mathrm{cfu} / \mathrm{L} . \mathrm{h}, 4.5 \times 10^{10} \mathrm{cfu} / \mathrm{L}$.h and $7.6 \times 10^{9} \mathrm{cfu} / \mathrm{L}$.h, respectively, whereas these values of $B$. lactis $\mathrm{Bb}-12$ and $B$. longum $\mathrm{Bb}-46$ probiotic strains were $2.7 \times 10^{9} \mathrm{cfu} / \mathrm{L}$.h and $1.0 \times 10^{10} \mathrm{cfu} / \mathrm{L}$.h. The $\alpha$-galactosidase activities were also detected in the intracellular fraction of the disrupted cells. Productions of lactic and acetic acids were in the range of $23-60 \mathrm{mmol} / \mathrm{L}$ and $2.4-5.6 \mathrm{mmol} / \mathrm{L}$, respectively. Molar ratios of acetate to lactate in all tested strains varied from $0.05-0.1$ that are very promising for further technological development of probiotic fermented soy-based food products.
\end{abstract}

Keywords: bifidobacteria, soymilk, short chain fatty acid (SCFA), fermentation, probiotic, $\alpha$-galactosidase, galacto-oligosaccharides

\section{Introduction}

Soybean (Glycine max. L. Merr) is one of the most important oleaginous seeds in the world due to availability and rich in high quality proteins, essential amino acids, calcium, phosphorus, iron, vitamins (especially A and B) and vegetable oil [1]. Soy-based foods may provide a range of health benefits through

*Corresponding author; E-mail: quang.nguyenduc@uni-corvinus.hu 
hypolipidemic, anticholesterolemic and antiatherogenic properties as well as reduction in allergenicity [2, 3] and risk of most hormone-associated health disorders [4]. Evidences are available that consumption of soy-derived food had potential health benefits related to cardiovascular diseases, menopausal symptoms, osteoporosis, breast and prostate cancers because they are rich sources of bioactive phenolic compounds [5, 6]. Moreover, soybean contains all amino acids essential to human nutrition, thus it should be a good food base for substitution of milk for those who are vegetarians or lactose-intolerant [7, 8]. However, consumption of soymilk is hindered due to the presence of unpleasant off-flavours carried over from soybean as well as various oligosaccharides including raffinose and stachyose that may cause a gastrointestinal discomfort known as flatulence to consumers [9]. Raffinose and stachyose are non-digestible $\alpha$-galactosidic oligosaccharides due to lack of $\alpha$-galactosidase in the human gastrointestinal tract. These matters can be addressed and eliminated by treatment using external $\alpha$-galactosidase enzyme or/and fermentation with microorganism possessing high $\alpha$-galactosidase activity. The latter concept should be more attractive from all scientific, technical and nutritional points of view, because in one processing step there is possibility to remove off-flavour effects causing by $n$-hexanal and pentanal (mainly occurring in beans and formed from unsaturated fatty acids) [9]; and production of probiotic products with high nutritional values. In the last few decades, intensive research dealing with fermentation of soymilk using mainly Lactobacillus and Bifidobacterium strains was carried out worldwide [10-14]. Hydrolysis of isoflavones as well as production of flavourful lactic acid during fermentation of soymilk was reported by Bordignon et al. in 2004 [15]. Reduction of galacto-oligosaccharides (raffinose, stachyose, soygalacto-oligosaccharides, etc.) by various lactic acid bacteria (Lb. cellobiosis, Lb. plantarum, Lb. curvatus, Lb. fermentum, Lb. pentosus, etc.) have also been reported by several authors [16].

Nowadays, several Bifidobacterium strains are well known as probiotics with many health-promoting effects, and they play an important role in the microbial ecology of the human and animal gut [17-24]. Moreover, some strains of this genus were also reported to be capable of metabolising $\alpha$-galactosyl type galacto-oligosaccharides $[25,26]$, thus soymilk that contains sucrose, raffinose, stachyose, proteins, vitamins, etc., should be a good medium for growing bifidobacteria [25]. This hypothesis was also proved by Bordignon et al. [15] when they reported that B. bifidum JCM 1255, B. breve JCM 1922 and B. infantis JCM 1222 strains preferentially fermented galacto-oligosaccharides rather than sucrose, during fermentation of soymilk. Although, due to $\alpha$-galactosidase activity, Bifidobacteria are able to cleave $\alpha$-galactosidic bonds, very few data are available in the literature related to properties of the $\alpha$-galactosidase enzyme from this 
micro-organism. Generally, Bifidobacterium spp. utilise glucose through the socalled "bifidus pathway" resulting in high levels of short chain fatty acids (SFCA) including lactic, propionic, butyric, acetic acid, etc. Meanwhile, lactic acid is a flavourful compound, whereas the presence of acetic acid causes odour defects in the final product, and thus it could be a main drawback of application of bifidobacteria in a fermentation system. However there is no doubt that the molar ratio of lactic and acetic acid varies from species to species, even from strains to strains and also fermentation conditions. In the case of lactic acid bacteria, some authors $[27,28]$ reported that an increased supplement of nitrogen source resulted in higher concentrations of lactic acid, and thus the flavour of a product should be better. In our previous study [29], this effect was also observed when studying fermentation of carrot juice with several Bifidobacterium strains. In this study, performances of newly isolated, human origin Bifidobacterium strains on the fermentation of soymilk were focused.

\section{Materials and Methods}

\section{Media}

Trypticase-Phytone-Yeast medium (TPY) contained (per litre) trypticase (BBL) $10 \mathrm{~g}$, phytone (BBL) $5 \mathrm{~g}$, glucose $5 \mathrm{~g}$, yeast extract (Difco) $2.5 \mathrm{~g}$, Tween $801 \mathrm{ml}$, L-cysteine $\mathrm{HCl} 0.5 \mathrm{~g}, \mathrm{~K}_{2} \mathrm{HPO}_{4} 2 \mathrm{~g}, \mathrm{MgCl}_{2} * 6 \mathrm{H}_{2} \mathrm{O} 0.5 \mathrm{~g}, \mathrm{ZnSO}_{4} * 7 \mathrm{H}_{2} \mathrm{O}$ $0.25 \mathrm{~g}, \mathrm{CaCl}_{2} 0.15 \mathrm{~g}, \mathrm{FeCl}_{3} 0.03 \mathrm{~g}, \mathrm{pH}$ ca. 6.0.

Soymilk: Soybeans were washed and soaked in water for one day at room temperature. Soaking water was drained and beans boiled in fresh water (its quantity was the quadruple of the soybeans) for 30 minutes, then the whole amount was crushed with mixer for 5 minutes and filtered through double-layer cloth to yield soymilk. The cake was extracted several times to gain approximately 4.5-5 litres soymilk per 500 g soybean. It was autoclaved at $121{ }^{\circ} \mathrm{C}$ for 15 minutes.

\section{Microorganisms and their cultivation}

Bifidobacterium lactis $\mathrm{Bb}-12$ and $B$. longum $\mathrm{Bb}-46$ were purchased from Chr. Hansen A/S (Hørsholm, Denmark). Bifidobacterium bifidum B3.2, B. bifidum B7.1 and B. breve B9.14 were isolated from human faeces and identified [30]. All Bifidobacterium strains were pre-cultured anaerobically (in Bugbox anaerobic chamber, Ruskin Technology) in TPY medium at $37{ }^{\circ} \mathrm{C}$ for approximately $24 \mathrm{~h}$. 


\section{Fermentation}

Fermentation was initiated with $10^{6}-10^{7} \mathrm{CFU}$ (colony forming unit) $/ \mathrm{mL}$ concentration of the relevant Bifidobacterium strains. All trials were carried out under anaerobe conditions in Anaerobe Jar+GasPak System (OXOID) or in Bugbox anaerobic chamber at $37^{\circ} \mathrm{C}$. Fermentation was followed by determining viable cell counts, measuring $\mathrm{pH}$ and titratable acidity.

\section{Analytical procedures}

Titratable acidity $\left(\mathrm{SH}^{\circ}\right)$ and $\mathrm{pH}$ : The titratable acidity was determined with Soxhlet-Henkel method by titration. During cultivation, the main metabolic products are organic acids, particularly lactic and acetic acids. The $\mathrm{pH}$ changes in batches of soymilk or TPY media were monitored during fermentation using a SevenMulti pH-meter (Metler Toledo, USA).

Viable counts: The plate counts of bifidobacteria were determined on Beeren's agar [29] or TPY agar. Samples from the fermented broth were diluted by 10 -fold serial dilution and aliquots were transferred into Petri dishes and mixed with the molten cooled medium $\left(37^{\circ} \mathrm{C}\right)$. After solidification, the plates were incubated under anaerobic conditions at $37^{\circ} \mathrm{C}$. The colonies were counted after $48 \mathrm{~h}$ or $72 \mathrm{~h}$ incubation.

Determination of organic acids: The concentrations of organic acids were determined with Waters HPLC System consisting of W610 pump Waters HPLC Controller, 717 plus autosampler W410 refractive index (RI), and photodiode array (PDA) detectors. A thermostatically controlled column compartment set at $45{ }^{\circ} \mathrm{C}$ containing Aminex HPX-87H ion exclusion column was used at a flow rate of $0.6 \mathrm{~mL} / \mathrm{min}$ using $5 \mathrm{mM} \mathrm{H}_{2} \mathrm{SO}_{4}$ as the mobile phase. The data acquisition and integration were performed using the Millenium ${ }^{\mathrm{TM}} 4.0$ software package. Each sample was injected three times. Standards (external and internal) of organic acids (lactic, acetic, malic, citric, succinic, $\mathrm{H}_{2} \mathrm{SO}_{4}$ and oxalic) were used to identify and quantify the components in the samples.

Enzyme activity assay: The $\alpha$-galactosidase enzyme activity was assayed in the reaction mixture containing $0.3 \mathrm{~mL}$ of McIlvaine buffer $(100 \mathrm{mM}$, at $\mathrm{pH}$ 6.6) and $0.5 \mathrm{~mL}$ of $15 \mathrm{mM}$-nitrophenyl $\alpha$-D-galactopyranoside (pNP $\alpha \mathrm{Gal})$ substrate. The cells were disrupted by a chemical method (Cetyl trimethylammonium bromide, CTAB) and the intracellular fraction was used for assaying enzyme activity. Buffered substrate was pre-incubated at the relevant temperature for $5 \mathrm{~min}$ and the enzyme reaction was started by adding $0.2 \mathrm{~mL}$ of adequately diluted enzyme solution. After 5 min the enzyme reaction was stopped by add- 
ing $5 \mathrm{~mL}$ of $0.1 \mathrm{M} \mathrm{Na}_{2} \mathrm{CO}_{3}$ solution. The released p-nitrophenol was determined spectrophotometrically at $405 \mathrm{~nm}$ using linear calibration prepared with p-nitrophenol under the same conditions.

One unit (U) of enzyme activity was defined as the amount of enzyme that releases one $\mu \mathrm{mol}$ p-nitrophenol per min under the standard conditions.

\section{Statistical analysis}

All data are presented as the mean and standard deviation (SD). One-way analysis of variance (ANOVA), unpaired and paired Student's $t$-tests were done using Statistica v9.0 software package (StatSoft, USA). Generally, only $\mathrm{p}<0.05$ was accepted as the statistical significance level.

\section{Results and Discussion}

Growth, volumetric productivity and $\alpha$-galactosidase activity of bifidobacteria

The most important factor in developing technology for the production of probiotic foodstuffs is growth and viability of applied strain(s). The international standards recommend that the fermented products claiming health benefits must contain a minimum of $10^{7}$ viable probiotic bacteria per gram of product at the time of purchase [29]. The changes in viable cells of bifidobacteria during fermentation of soymilk are presented in Figure 1. Generally, maximum counts of cell numbers occurred at the $12^{\text {th }}$ hour of fermentation except for B. bifidum B3.2 strain in independent of the initial cell concentration (from about $5 \times 10^{6} \mathrm{cfu} / \mathrm{mL}$ to $10^{7} \mathrm{cfu} / \mathrm{mL}$ ). The counts of most strains varied from $5 \times 10^{7}$ to $10^{8} \mathrm{cfu} / \mathrm{mL}$, in the case of B. bifidum B7.1 about $5 \times 10^{8} \mathrm{cfu} / \mathrm{mL}$ were counted as in the case of B. bifidum B3.2 at $24 \mathrm{~h}$ of fermentation of soymilk. These numbers are significantly higher than the counts of B. lactis Bb-12 and B. logum Bb-46 that are probiotic strains. Both B. bifidum B3.2 and B7.1 strains are the new isolates and deposited in the National Collection of Agricultural and Industrial Microorganisms, Budapest. Shimakama et al. [36] also reported that B. breve strain Yakult needed about 12 hours to reach stationary phase with about $4 \times 10^{9} \mathrm{cfu} / \mathrm{mL}$ (from about $5 \times 10^{7} \mathrm{cfu} / \mathrm{mL}$ ). Our results differ from those reported by Hou et al. [37] or Wang et al. [13] when they studied growth of B. infantis and B. longum in soymilk. 


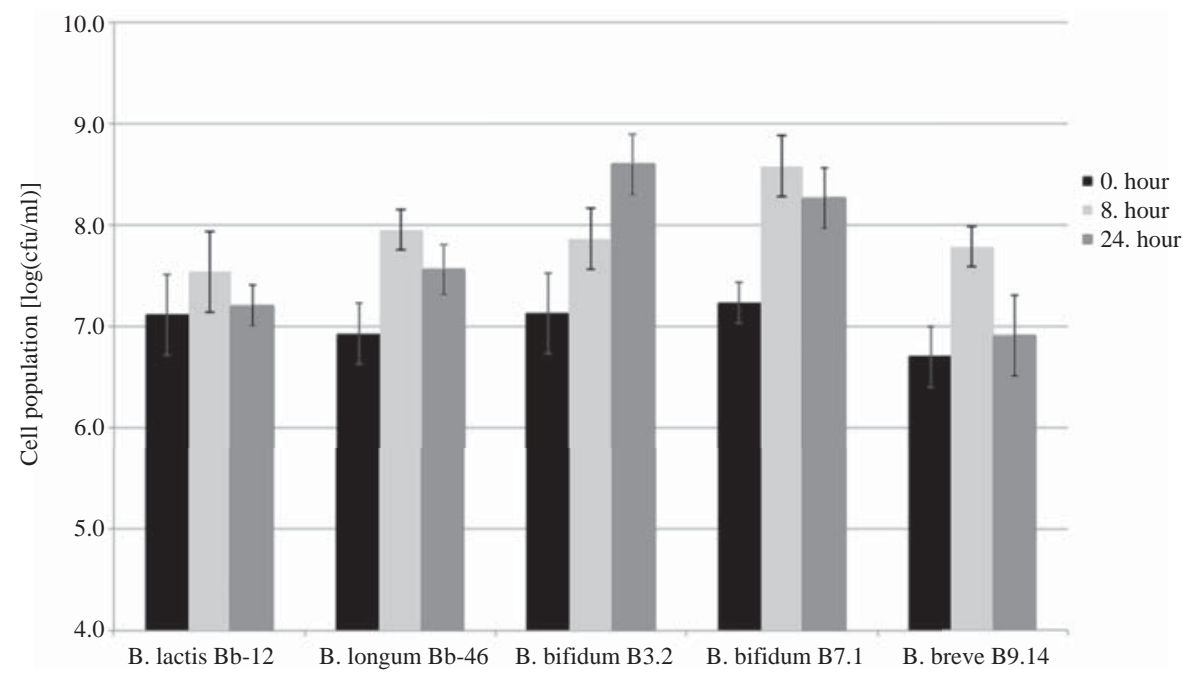

Figure 1. Growth of Bifidobacterium spp. in soymilk

They found that both B. infantis CCRC 14633 and B. longum B6 strains take at least 24 hours to reach maximum cell numbers in native soymilk.

Volumetric productivities of B. bifidum B3.2, B. bifidum 7.1 and B. breve B9.14 were $1.6 \times 10^{10} \mathrm{cfu} / \mathrm{L} . \mathrm{h}, 4.5 \times 10^{10} \mathrm{cfu} / \mathrm{L}$.h and $7.6 \times 10^{9} \mathrm{cfu} / \mathrm{L}$.h, respectively. These values were significantly higher that those of probiotic strains $B$. lactis Bb-12 $\left(2.7 \times 10^{9} \mathrm{cfu} / \mathrm{L} . \mathrm{h}\right)$ and B. $\log u m$ Bb-46 $\left(1.0 \times 10^{10} \mathrm{cfu} / \mathrm{L} . \mathrm{h}\right)$ as well as were not far from volumetric productivities of some bifidobacteria in carrot juice [29]. In the case of B. lactis $\mathrm{Bb}-12$ strain, productivity was less in soymilk $\left(2.7 \times 10^{9}\right.$ cfu/L.h) compared with MRS medium $\left(1.1 \times 10^{10} \mathrm{cfu} / \mathrm{L}\right.$.h) [38]. Generally, the volumetric productivity of bifidobacteria in soymilk is less than in milk, even when the same strains are used $[11,39,40]$. Our results are also in agreement with this observation.

Minimal decreases in saccharides concentration during fermentation were detected (data are not shown). Interestingly, few data are available in the literature about $\alpha$-galactosidase from B. lactis $\mathrm{Bb}-12$ and $B$. $\log u m$ Bb-46 that are widely applied as probiotics strains in the dairy industry. In fact, in milk based products, lactose is present as the main sugar, and bacteria should synthetise $\beta$-galactosidase to utilise it. In soymilk, galactose based-(oligo)saccharides (mainly $\alpha$-galactosides) are an important part of the total carbohydrate content, thus to grow on this type substrate, the bifidobacteria have to secrete $\alpha$-galactosidase enzyme. Desjardins et al. [31] observed that bifidobacteria possessed high activi- 
ties of $\alpha$-galactosidase and $\beta$-galactosidase using API ZYM kit. Bifidobacterium adolescentis DSM 20083 strain secreted $\alpha$-galactosidase extracellularly; that was suggested to be a tetrametric structure of the protein [32]. Later, two groups - Goulas et al. [33] as well as Zhao et al. [34] - reported cloning, expression and characterisation of $\alpha$-galactosidase from B. bifidum NCBIM B41171 and B. breve 203 , respectively, and it had been found a monomeric nature of this galactosidase with molecular mass about $80 \mathrm{kDa}$. Tochikura et al. [35] however, found that bifidobacteria exhibit higher hydrolyzing activity toward various p-nitrophenyl glycosides than other intestinal bacteria. In our study, the raffinose as the inducer was applied to check the production of $\alpha$-galactosidase by new isolates of the bifidobacteria. The laboratory media were supplemented with $1 \%$ (mass per volume) raffinose and then cultured with ca. $10^{7} \mathrm{cfu} / \mathrm{ml}$ of different Bifidobacterium strains. Not any $\alpha$-galactosidase activities were measured in the ferment broth (the extracellular fraction). After disruption of bacterial cells, the $\alpha$-galactosidase activity was detected meaning the bacteria synthetized it intracellularly. Similar $\alpha$-galactosidase activity was observed the $B$. bifidum B7.1 strain comapring with the $B$. lactic $\mathrm{Bb}-12\left(3 \times 10^{-11} \mathrm{U} / \mathrm{cfu}\right)$. In the cases of the B. bifidum $\mathrm{B} 3.2$ and the $B$. breve $\mathrm{B} 9.14$ strains low $\alpha$-galactosidase activities were observed, even they were grown very well.

\section{Changes in titratable acidity and $p H$}

During fermentation of soymilk, the titratable acidity (TA) increased from about $3 \mathrm{SH}^{\circ}$ to the range 14.27-29.32 $\mathrm{SH}^{\circ}$ depending on the strain used; meanwhile the $\mathrm{pH}$ value decreased from 6 to 4.5 (Figure 2). The highest acidity $\left(29 \mathrm{SH}^{\circ}\right)$ was observed in the case of B. bifidum B3.2 strain. Intensive growth of bacteria was also confirmed by the drop in $\mathrm{pH}$ in the first 8 hours of fermentation (Figure 2). In general, pH values dropped from 6.0 to 5.0 or below. In 2003, Wang et al. [13] reported that in similar situations, $B$. infantis CCRC 14633 takes about 40 hours and 48 hours of fermentation to reach $\mathrm{pH} 5.04$ and $\mathrm{pH} 4.61$, respectively. Bifidobacterium breve JCM 1192 strain was reported to achieve a better fermentation profile (drop in $\mathrm{pH}$ from 6.2 to 5.1 after $16 \mathrm{~h}$ ), while $B$. adolescentis JCM 1275 and B. bifidum JCM 1255 produced less acid during fermentation of soymilk [15]. Our results are comparable to some profiles produced by lactic acid bacteria such as Lactobacillus delbrueckii subsp. bulgaricus IFO 13953 [15]. Lb. casei subsp. rhamnosus FNCC 098, Lb. plantarum SMN 25, Lb. plantarum pentosus SMN 01 [41]. 

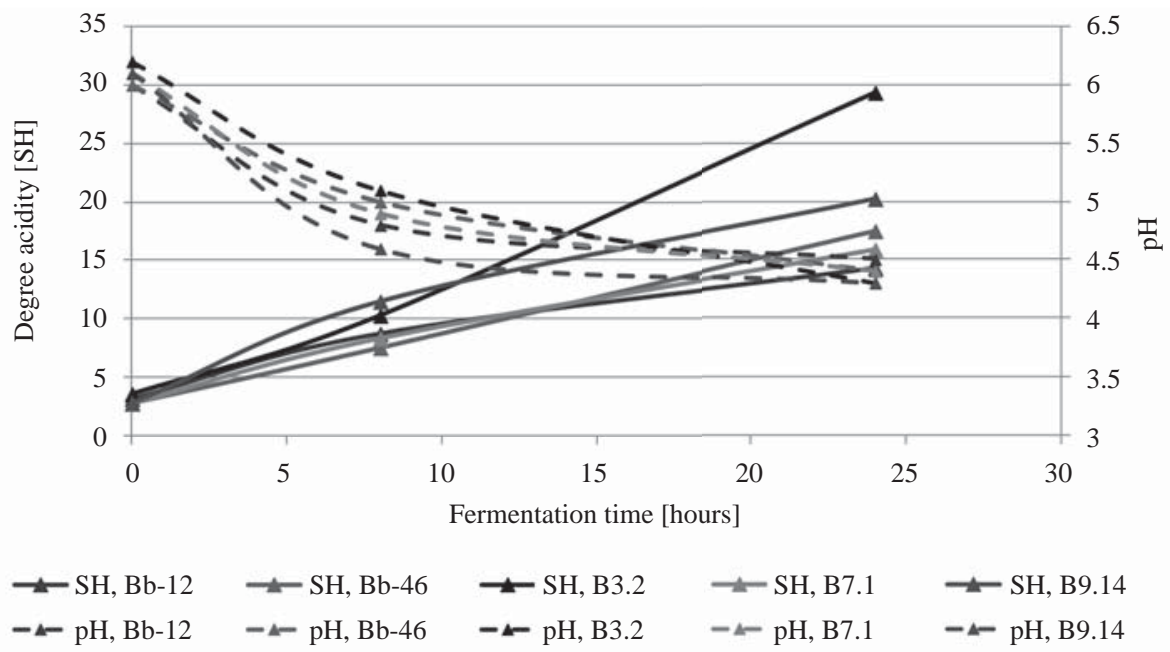

Figure 2. The profile of the acidity and $\mathrm{pH}$ of the soymilk fermentation with bifidobacteria

\section{Changes in lactic, acetic and propionic acid concentration}

It is well known that lactic acid is one of most important compounds in formation of the flavor of fermented products such as soymilk. One unique aspect of bifidobacteria is that all the lactic acid produced is in the $\mathrm{L}(+)$ form which is more easily metabolized by infants than the $\mathrm{D}(-)$ form [42]. Theoretically, utilisation of carbohydrates through the "bifidus" pathway, the bifidobacteria, produces more acetic acid than lactic acid (generally 3:2 in molar ratio) [43]. Changes in some organic acids in soymilk during fermentation with four applied Bifidobacterium strains are summarized in Table I. Due to intensive metabolic activity, both new isolates: B. bifidum B7.1 and B. bifidum B3.2 strains produced high amount of lactic and acetic acids in fermentation of soymilk even after 6 hours (in the case of B7.1 $51.36 \mathrm{mmol} / \mathrm{L}$ lactic and $2.65 \mathrm{mmol} / \mathrm{L}$ acetic acid, in the case of B3.2, $43.61 \mathrm{mmol} / \mathrm{L}$ and $3.43 \mathrm{mmol} / \mathrm{L}$, respectively). The lactic acids content in the fermented soymilk increased to $58.14 \mathrm{mmol} / \mathrm{L}$ and $58.55 \mathrm{mmol} / \mathrm{L}$ in the cases of B. bifidum B7.1 and B3.2 strains, respectively, whereas about the increase of acetic acid was about $2 \mathrm{mmol} / \mathrm{L}$ after 12 of fermentation process. The production of short chain fatty acids by the new isolates are comparable with commercial strain B. lactic Bb-12 and significantly better than B. longum Bb-46. Additionally, our results were about ten times higher than those reported by Donkor et al. [44]. In their study, B. lactis B94 and B. longum B1536 produced 0.02 and $0.03 \mathrm{mg} / \mathrm{mL}$ lactic acid and $0.05 \mathrm{mg} / \mathrm{ml}$ acetic acid concentration at the $12^{\text {th }}$ hours of soymilk fermentation. Higher acetic acid concentrations were 
Table I. Changes of lactic, acetic and propionic acid in soymilk fermented with different Bifidobacterium strains

\begin{tabular}{|c|c|c|c|c|}
\hline \multirow{2}{*}{$\begin{array}{l}\text { Fermentation } \\
\text { time (h) }\end{array}$} & \multicolumn{3}{|c|}{ Content $(\mathrm{mmol} / \mathrm{L})$} & \multirow{2}{*}{$\begin{array}{c}\text { Molar ratio } \\
\text { (acetic/lactic) }\end{array}$} \\
\hline & Lactic acid & Acetic acid & Propionic acid & \\
\hline \multicolumn{5}{|c|}{ B. bifidum B3.2 } \\
\hline 0 & $4.22 \pm 0.73$ & $0.72 \pm 0.52$ & $0.22 \pm 0.21$ & 0.17 \\
\hline 6 & $43.61 \pm 0.66$ & $3.43 \pm 0.81$ & $4.27 \pm 0.25$ & 0.08 \\
\hline 12 & $58.14 \pm 0.48$ & $5.57 \pm 0.71$ & $5.23 \pm 0.25$ & 0.10 \\
\hline \multicolumn{5}{|c|}{ B. bifidum B7.1 } \\
\hline 0 & $4.22 \pm 0.67$ & $0.72 \pm 0.47$ & $0.22 \pm 0.35$ & 0.17 \\
\hline 6 & $51.36 \pm 0.69$ & $2.65 \pm 0.25$ & $3.58 \pm 0.41$ & 0.05 \\
\hline 12 & $59.55 \pm 0.99$ & $4.59 \pm 0.62$ & $3.98 \pm 0.29$ & 0.08 \\
\hline \multicolumn{5}{|c|}{ B. lactis $\mathrm{Bb}-12$} \\
\hline 0 & $4.22 \pm 0.51$ & $0.72 \pm 0.44$ & $0.22 \pm 0.32$ & 0.17 \\
\hline 6 & $52.52 \pm 0.78$ & $4.44 \pm 0.39$ & $1.03 \pm 0.37$ & 0.08 \\
\hline 12 & $56.35 \pm 0.25$ & $5.01 \pm 0.42$ & $2.75 \pm 0.81$ & 0.09 \\
\hline \multicolumn{5}{|c|}{ B. longum $\mathrm{Bb}-46$} \\
\hline 0 & $4.22 \pm 0.55$ & $0.72 \pm 0.33$ & $0.22 \pm 0.27$ & 0.17 \\
\hline 6 & $16.12 \pm 0.61$ & $1.62 \pm 0.71$ & $0.75 \pm 0.24$ & 0.10 \\
\hline 12 & $23.68 \pm 0.84$ & $2.43 \pm 0.66$ & $0.82 \pm 0.24$ & 0.10 \\
\hline
\end{tabular}

published by Hou et al. [37], where they found that $11.32 \mathrm{mmol} / \mathrm{L}$ and 11.42 $\mathrm{mmol} / \mathrm{L}$ acetic acid concentrations were determined after $12 \mathrm{~h}$ of fermentation using B. infantis CCRC 14633 and B. longum B6 strains, respectively. Based on molar ratio of acetic to lactic acid calculated, in the first stage of fermentation these values were about 1.8-1.9, thus B. infantis CCRC 14633 and B. longum B6 did not follow only the bifidus pathway. Interestingly, all of investigated strains in our study produced much more lactate than acetate in molarity $(0.05-0.10$ molar ratio). Our present results confirm data reported in our previous study [29] on fermentations of carrot juice. Some studies dealing with nutrients necessary for lactic acid fermentation have been established [27-28]. They found that supplementing with more nitrogenous components resulted in higher concentrations of lactic acid. Soymilk is rich in protein and amino acid content, thus it may result in changes of molar ratio of acetate to lactate during fermentation. Furthermore, these results demonstrated that the molar ratio of acetic and lactic acids 
produced by bifidobacteria varies depending on numerous parameters such as applied strains, culture medium, the fermentation time, even fermentation conditions, etc.

\section{Conclusions}

All investigated human origin Bifidobacterium strains (B. bifidum B3.2, B. bifidum $\mathrm{B} 7.1$ and $B$. breve $\mathrm{B} 9.14$ ) were able to grow and ferment native soymilk without any nutrient supplementation like the commercial probiotic ones $B$. lactis $\mathrm{Bb}-12$ and $B$. longum $\mathrm{Bb}-46$. These strains produce high levels of lactic acid in fermented soymilk that resulted in titratable acidities in the range of 14 to $29 \mathrm{SH}^{\circ}$. Moreover, the molar ratios of acetate to lactate concentration at $12 \mathrm{~h}$ of fermentation varied from 0.05 to 0.1 that are very good results from technological points of view, since high concentration of acetic acid causes odour defects in the final product. Overall, the performances of newly isolated, human origin Bifidobacterium strains on fermentation of native soymilk were comparable with the industrial ones, thus our results are very promising and may serve as base for developing the technology for production of probiotic fermented soymilk.

\section{Acknowledgements}

This research is supported by the National Development Agency (Project No. TÁMOP-4.2.1./B-09/1-KMR-2010-0005 and TÁMOP-4.2.2/B-10/1-2010-0023) and the National Office for Research and Technology (Project No. NKFP4/002/ 2004). Dr. Quang D. Nguyen received the Bolyai János Research Grant from the Hungarian Academy of Sciences, Budapest, Hungary.

\section{Conflict of Interest}

No conflict of interest.

\section{References}

1. Genta, H. D., Genta, M. L., Álvarez, N. V., Santana, M. S.: Production and acceptance of soy candy. J Food Eng 53, 199-202 (2002).

2. Beasley, S., Tuorila, H., Saris, P. E. J.: Fermented soymilk with a monoculture of Lactococcus lactis. Inter J Food Microb 81, 159-162 (2001). 
3. Favaro Trindade, C. S., Terzi, S. C., Trugo, L. C., Della Modesta, R. C., Couri, S.: Development and sensory evaluation of soymilk based yoghurt. Arch Latinoamer Nutr 51, 100-104 (2001).

4. Kurzer, M. S.: Hormonal effects of soy isoflavones: Studies in premenopausal and post-menopausal women. J Nutr 130, 660-661 (2000).

5. Devi, M. K. A., Gondi, M., Sakthivelu, G., Giridhar, P., Rajasekaran, T., Ravishankar, G. A.: Functional attributes of soybean seeds and products, with reference to isoflavone content and antioxidant activity. Food Chem 114, 771-776 (2009).

6. Rodríguez-Roque, M. J., Rojas-Graü, M. A., Elez-Martínez, P., Martín-Belloso, O.: Soymilk phenolic compounds, isoflavones and antioxidant activity as affected by in vitro gastrointestinal digestion. Food Chem 136, 206-212 (2013).

7. Scalabrini, P., Rossi, M., Spetolli, P., Matteuzzi, D.: Characterization of Bifidobacterium strains for use in soymilk fermentation. Inter J Food Microb 39, 213-219 (1998).

8. Mishra, S., Mishra, H. N.: Technological aspects of probiotic functional food development - A review. Nutrafoods 11, 117-130 (2012).

9. Arai, S., Suzuky, H., Fujimake, M., Sakurai, Y.: Studies on flavour components in soybean. Part 2. Phenolic acids in defatted soybean flour. Agr Biol Chem 30, 364-369 (1996).

10. Granta, L. A., Morr, C. V.: Improved acid, flavour and volatile compound production in a high protein and fiber soymilk yogurt-like product. J Food Sci 61, 331-336 (1996).

11. Garro, M. S., de Valdez, G. F., de Giori, G. S.: Temperature effect on the biological activity of Bifidobacterium longum CRL 849 and Lactobacillus fermentum CRL 251 in pure and mixed cultures grown in soymilk. Food Microb 21, 511-518 (2004).

12. Wang, Y. J., Yu, R. C., Chou, C. C.: Growth and survival of bifidobacteria and lactic acid bacteria during the fermentation and storage of cultured soymilk drink. Food Microb 19, 501-508 (2002).

13. Wang, Y. C., Yu, R. C., Yang, H. Y., Chou, C. C.: Sugar and acid contents in soymilk fermented with lactic acid bacteria alone or simultaneously with bifidobacteria. Food Microb 20, 333-338 (2003).

14. Wang, J., Guo, Z., Zhang, Q., Yan, L., Chen, W., Liu, X. M., Zhang, H. P.: Fermentation characteristics and transit tolerance of probiotic Lactobacillus casei Zhang in soymilk and bovine milk during storage. J Dairy Sci 92, 2468-2476 (2009).

15. Bordignon, J. R., Nakahara, K., Yoshihashi, T., Nikkuni, S.: Hydrolysis of isoflavones and consumption of oligosaccharides during lactic acid fermentation of soybean milk. Japan Agri Res Quartly 38, 259-265 (2004).

16. Yoon, M. Y., Hwang, H. J.: Reduction of soybean oligosaccharides and properties of $\alpha$-galactosidase from Lactobacillus curvatus R08 and Leuconostoc mesenteriodes JK55. Food Microb 25, 815-823 (2008).

17. Saarela, M., Lahteenmaki, L., Crittenden, R., Salminen, S., Mattila-Sandholm, T.: Gut bacteria and health foods - The European perspective. Inter J Food Microb 78, 99-117 (2002).

18. Fuller, R.: Probiotics in man and animals. J Appl Bacter 66, 365-568 (1989).

19. Jiang, T., Mustapha, A., Savaiano, D. A.: Improvement of lactose digestion in humans by ingestion of unfermented milk containing Bifidobacterium longum. J Dairy Sci 79, 750757 (1996).

20. Mercenier, A., Pavan, S., Pot, B.: Probiotics as biotherapeutic agents: Present knowledge and future prospects. Curr Pharm Design 8, 99-110 (2002). 
21. Schiffrin, E. J., Rochat, F., Link-Amster, H., Aeschlimann, J. M., Donnet-Hughes, A.: Immunomodulation of human blood cells following the ingestion of lactic acid bacteria. J Dairy Sci 78, 491-497 (1995).

22. St-Onge, M. P., Farnworth, E. R., Jones, P. J. H.: Consumption of fermented and nonfermented dairy products: Effects on cholesterol concentrations and metabolism. Am J Clin Nutr 71, 674-681 (2000).

23. Tamine, A. Y., Marshall, V. M., Robinson, R. K.: Microbiological and technological aspects of milks fermented by bifidobacteria. J Dairy Sci 62, 151-187 (1995).

24. Suskovic, J., Kos, B., Goreta, J., Matosic, S.: Role of lactic acid bacteria and bifidobacteria in synbiotic effect. Food Technol Biotechnol 39, 227-235 (2001).

25. Kamaly, K. M.: Bifidobacteria fermentation of soybean milk. Food Res Inter 30, 675-682 (1997).

26. Kullen, M. J., Khil, J., Busta, F. F., Gallaher, D. D., Brady, L. J.: Carbohydrate source and bifidobacteria influence the growth of Clostridium perfringens in vivo and in vitro. Nutr Res 18, 1889-1897 (1998).

27. Kwon, S., Lee, P. C., Lee, E. G., Chang, Y. K., Chang, N.: Production of lactic acid by Lactobacillus rhamnosus with vitamin-supplemented soybean hydrolysate. Enzyme Microb Technol 26, 209-215 (2000).

28. Nancid, N., Nancid, A., Boudjelal, A., Benslimane, C., Blanchard, F., Boudrant, J.: The effect of supplementation by different nitrogen sources on the production of lactic acid from date juice by Lactobacillus casei subsp. rhamnosus. Biores Technol 78, 149-153 (2001).

29. Kun, Sz., Rezessy-Szabó, J. M., Nguyen, Q. D., Hoschke, Á.: Changes of microbial population and some components in carrot juice during fermentation with selected Bifidobacterium strains. Proc Biochem 43, 816-821 (2008).

30. Mayer, Á., Rezessy-Szabó, J., Bognár, Cs., Hoschke, Á.: Research for creation of functional foods with Bifidobacteria. Acta Aliment 32, 27-39 (2003).

31. Desjardins, M. L., Roy, D., Goulet, J.: Growth of bifidobacteria and their enzyme profiles. J Dairy Sci 73, 299-307 (1990).

32. Leder, S., Hartmeier, W., Marx, P.S.: $\alpha$-Galactosidase of Bifidobacterium adolescentis DSM 20083. Curr Microb 38, 101-106 (1999).

33. Goulas, T., Goulas, A., Tzortzis, G., Gibson, R. G.: A novel $\alpha$-galactosidase from Bifidobacterium bifidum with transgalactosylating properties: Gene molecular cloning and heterologous expression. Appl Microb Biotechnol 82, 471-477 (2009).

34. Zhao, H., Lu, L., Xiao, M., Wang, Q., Lu, Y., Liu, C., Wang, P., Kumagai, H., Yamamoto, K.: Cloning and characterization of a novel $\alpha$-galactosidase from Bifidobacterium breve 203 capable of synthesizing Gal- $\alpha-1,4$ linkage. FEMS Microb Lett 285, 278-283 (2008).

35. Tochikura, T., Sakai, K., Fujiyoshu, T., Tachiki, T., Kumagai, H.: p-Nitrophenyl glycoside-hydrolyzing activities in Bifidobacteria and characterization of $\beta$-d-galactosidase of Bifidobacteium longum 401. Agri Biol Chem 50, 2279-2286 (1986).

36. Shimakama, Y., Matsubara, S., Yuki, N., Ikeda, M., Ishikawa, F.: Evaluation of Bifidobacterium breves strain Yakult-fermented soymilk as a probiotic food. Int J Food Microbiol 81, 131-136 (2003).

37. Hou, J. W., Yu, R. C., Chou, C. C.: Changes in some components of soymilk during fermentation with bifidobacteria. Food Res Inter 33, 393-397 (2000).

38. Heenan, C. N., Adams, M. C., Hosken, R. W., Fleet, G. H.: Growth medium for culturing probiotic bacteria for application in vegetarian food products. Lebensmittel-Wissenschaft Technologie 35, 171-176 (2002). 
39. Ventling, B. L., Mistry, V. V.: Growth characteristics of bifidobacteria in ultrafiltrated milk. J Dairy Sci 76, 962-971 (1993).

40. Doleyres, Y., Paquin, C., Leroy, M., Lacroix, C.: Bifidobacterium longum ATCC 15707 cell production during free and immobilized-cell cultures in MRS-whey permeate medium. Appl Microbiol Biotechnol 60, 168-173 (2002).

41. Sumarna: Changes of raffinose and stachyose in soymilk fermentation by lactic acid bacteria from local fermented foods of Indonesian. Malaysian J Microbiol 4, $26-34$ (2008).

42. Ishibashi, N., Shimamura, S.: Bifidobacteria: Research and development in Japan. Food Technol 6, 126-136 (1993).

43. De Vries, W., Stouthamer, A. H.: Pathway of glucose fermentation in relation to the taxonomy of bifidobacteria. J Bacteriol 93, 574-576 (1967).

44. Donkor, O. N., Henriksson, A., Vasiljevic, T., Shah, N. P.: $\alpha$-galactosidase and proteolytic activities of selected probiotic and dairy cultures in fermented soymilk. Food Chem 104, 10-20 (2007). 